\title{
EVALUATING GOVERNMENTAL RESPONSES TO COVID-19 AND THE IMPLICATIONS FOR TOURISM INDUSTRY
}

\author{
Jani KINNUNEN ${ }^{a *}$, Irina GEORGESCU ${ }^{b}$, Ane-Mari ANDRONICEANU ${ }^{c}$ \\ ${ }^{a}$ Åbo Akademi University, Finland \\ ${ }^{b, c}$ Bucharest University of Economic Studies, Romania
}

\begin{abstract}
The current Covid-19 pandemic is a disruptive event accompanied by a range of governmental responses and unforeseen impacts on society and businesses. We analyse and rank-order the effects of the national mitigation measures on the tourism sector of fifteen European countries and we build a composite Covid-Mitigatin Index, CMI, for country comparisions. This is done using clustering and principal component analysis. The results are visualised and quantified, and their implications on decision makers within a tourism sector and governments are discussed. Daily data on national governmental responses to reduce the transmission of Covid-19, from January-May 2020, is obtained from Oxford Covid-19 Government Response Tracker. The data ranges from domestic and international travel restrictions, to banned gatherings, Covid-19 testing procedures and quarantine requirements among other variables. The effects of the national measures on tourism are studied using monthly market research data, from January-May 2020, on international (foreigners) and domestic (residents) travelers' bednights in European countries acquired mainly from a tourism marketing information system, TourMIS. The applied methodology uses, firstly, the K-means algorithm for the period February-April 2020 to cluster countries with similar responses and show dynamically, which countries have changed policies leading to changing also their reference cluster, accordingly. Secondly, a principal component analysis is conducted to find which response components related to containment and closure policies are linked to nights spent in the European countries under analysis. The implications of the results may be useful both for governmental decision making and for business preparedness in the future.
\end{abstract}

KEYWORDS: clustering, Covid-19, hospitality, tourism, principal component analysis.

\section{INTRODUCTION}

Covid-19 pandemic has hit hard on various industries (e.g., tourism industry - Štefko et al., 2020; business environment - Dvorsky et al., 2020; Besenyő \& Kármán, 2020; Dung et al., 2018). Due to strict international and domestic travel restrictions, tourism industry has been directly impacted. We will show, how by April 2020, international travel (measured by bednights) had totally stopped, while still in February, only few countries, such as Romania and Slovenia showed declines in tourism.

The European countries under analysis started their policy measures practically in March 2020 and only few mitigation measures had been taken by the end of February.

Temporary Covid mitigation policies along with longer-term policies, which restrict the functioning of the markets result in a decline of economic freedoms and economic activity (Pavlik \& Geloso, 2020; Kinnunen et al., 2019). Economic freedoms have been shown important conditions for

\footnotetext{
*Corresponding author. E-mail address: jani.kinnunen@abo.fi
} 
economic activity, e.g., in EU, OECD (Georgescu et al., 2018; Georgescu \& Kinnunen, 2019) and globally (De Haan \& Sturm, 2000). Further, Economic freedoms are related to entrepreneurial activity (Angulo-Guerrero et al., 2017; Kinnunen \& Gergescu, 2020a), which is an essential component of the hospitality and tourism industry (Lee-Ross \& Lashley, 2009, Ciochina et al. 2016).

The implications of Covid on tourism and economic activity in general have been analysed and they did not come unexpectedly (Androniceanu, 2020). For example, according to the United Nation's Report on Covid-19 and Tourism in 2020 (UN, 2020), the international tourism is among the economic sectors which is suffering the most from the pandemic crisis. Tourism sector is an important part of world economy (Mura \& Kajzar, 2019). The report simulates short-term international tourism to obtain pessimistic, intermediate and optimistic scenarios. The pessimistic scenario assumes that all inbound tourism expenditures for one year are removed in each country; the intermediate scenario assumes that $2 / 3$ of inbound tourism expenditure for one year are removed; while the optimistic scenario assumes that $1 / 3$ of inbound tourism expenditures are removed. According to an OECD Policy report on Coronavirus from June 2020 (OECD, 2020a), world countries have taken measures to respond to Covid-19, "liquidity injections and fiscal reliefs”, such as loans, holiday vouchers, rule changes in order to protect tourism consumers (Kostynets et al., 2020). Studies have focused on negative implications of the pandemic, while the positive implications are limited, specifically, to the use of technology (cf. Kinnunen \& Georgescu, 2020b; Poór et al., 2020; Razif et al., 2020; Akeel \& Khoj, 2020).We study fifteen selected European countries and their policies to mitigate the pandemic. We start by a clustering procedure to show which European countries are similar with each other by their Covid-19 mitigation measures. The dynamic monthly clustering will reveal, which countries have changed clusters during the research period. The changes will be described visually followed by cluster-wise analysis. The principal component method is then applied to find the most meaningful policy combinations, which form the principal components and to build a composite Covid-Mitigation Index, CMI, to compare the results and to reveal the most meaningful individual policies. Accordingly, the results are visualised and analysed, and the mitigation factors are ranked and their implications are quantified. The rest of the paper is structured as follows. Section 2.1 presents the data variables and data values for March 2020, which is the focus of this study, and Section 2.2 describes the used methods, i.e., the K-means clustering and Principal Component Analysis, PCA. Section 3.1 presents and discusses the results from the K-means analysis and 3.2 from the PCA. Section 4 concludes the paper.

\section{DATA AND METHODS}

\subsection{Data}

The data was collected for 15 European countries: Austria (AUT), Belgium (BEL), Czech Republic (CZE), Denmark (DEN), Finland (FIN), Germany (GER), Hungary (HUN), Netherlands (NED), Norway (NOR), Poland (POL), Portugal (PRT), Romania (ROM), Slovenia (SVN), Sweden (SWE) and Switzerland (CHE) for the period from January to June 2020 from the Austrian National Tourist office (2020b), Statistics Finland (2020b) and Romanian National Institute of Statistics (2020) on tourism and from Oxford COVID-19 Government Response Tracker (Hale et al., 2020) on governmental responses on the current pandemic.

Table 1 presents the variable descriptions and how we have handled the daily data by transforming it to monthly figures. 
Table 1. Variables description

\begin{tabular}{|c|c|c|}
\hline ID & Description & Coding of daily active policies \\
\hline C1 & $\begin{array}{l}\text { Record closings of schools and universities (sums up daily } \\
\text { codes for each month) }\end{array}$ & $\begin{array}{l}0 \text { - no measures, } 1 \text { - recommended, } 2 \text { - required, } 3 \text { - required closing all } \\
\text { levels }\end{array}$ \\
\hline C2 & $\begin{array}{l}\text { Record closings of workplaces (sums up daily codes for each } \\
\text { month) }\end{array}$ & as above \\
\hline C3 & $\begin{array}{l}\text { Cancellation of public events (sums up daily codes for each } \\
\text { month) }\end{array}$ & 0 - no measures, 1 - recommended, 2 - required \\
\hline C4 & $\begin{array}{l}\text { Restrictions on gatherings (sums up daily codes for each } \\
\text { month) }\end{array}$ & $\begin{array}{l}0 \text { - no measures, } 1 \text { - restrictions on gatherings }>1000 \text { people, } \\
2 \text { - between } 101-1000,3 \text { - between } 11-100,4-10 \text { or less }\end{array}$ \\
\hline C5 & $\begin{array}{l}\text { Record closing of public transport (sums up daily codes for } \\
\text { each month) }\end{array}$ & 0 - no measures, 1 - recommended, 2 - required \\
\hline C6 & $\begin{array}{l}\text { Stay at home requirements (sums up daily codes for each } \\
\text { month) }\end{array}$ & $\begin{array}{l}0 \text { - no measures, } 1 \text { - recommended, } 2 \text { - required with some exceptions, } \\
3 \text { - required with minimal exceptions }\end{array}$ \\
\hline C7 & $\begin{array}{l}\text { Record restrictions on internal movement between } \\
\text { cities/regions (sums up daily codes for each month) }\end{array}$ & $\begin{array}{l}0 \text { - no measures, } 1 \text { - recommended not to travel, } 2 \text { - required not to } \\
\text { travel }\end{array}$ \\
\hline $\mathbf{C 8}$ & $\begin{array}{l}\text { Record restrictions on international travel of foreigners (sums } \\
\text { up daily codes for each month) }\end{array}$ & $\begin{array}{l}0 \text { - no measures, } 2 \text { - quarantine at some arrivals, } 3 \text { - banned some } \\
\text { arrivals, } 4 \text { - total border closure }\end{array}$ \\
\hline H1 & $\begin{array}{l}\text { Record presence of public info campaigns (sums up daily } \\
\text { codes for each month) }\end{array}$ & $\begin{array}{l}0 \text { - no measures, } 1 \text { - public officials urging caution about Covid-19, } \\
2 \text { - coordinated public info campaign }\end{array}$ \\
\hline T1 & \multicolumn{2}{|c|}{$\begin{array}{l}\text { Domestic bednights, i.e. nights spent by residents in hotels and other accommodations (\%-change from a corresponding month a year } \\
\text { before) }\end{array}$} \\
\hline T2 & \multicolumn{2}{|c|}{$\begin{array}{l}\text { Foreign bednights, i.e. nights spent by non-residents in hotels and other accommodations (\%-change from a corresponding month a year } \\
\text { before) }\end{array}$} \\
\hline
\end{tabular}

Source: Austrian National Tourist Office (2020); Hale et al. (2020); Statistics Finland (2020b); Romanian National Institute of Statistics (2020)

Table 2 shows the data for the 15 countries and the averages for March, 2020, which is the month in the focus of our analysis.

Table 2. Data for March 2020 on Covid-19 responses and tourism

\begin{tabular}{|c|c|c|c|c|c|c|c|c|c|c|c|c|c|}
\hline ID & C1 & C2 & C3 & C4 & C5 & C6 & C7 & C8 & H1 & SI & EI & T1-\% & T2-\% \\
\hline AUT & 48 & 52 & 42 & 64 & 19 & 32 & 38 & 69 & 62 & 85 & 88 & -56 & -59 \\
\hline BEL & 36 & 51 & 40 & 56 & 0 & 28 & 36 & 64 & 62 & 81 & 88 & -66 & -68 \\
\hline CZE & 63 & 56 & 42 & 73 & 0 & 34 & 32 & 109 & 62 & 82 & 100 & -46 & -67 \\
\hline DNK & 57 & 35 & 26 & 71 & 22 & 29 & 19 & 97 & 62 & 72 & 38 & -34 & -52 \\
\hline FIN & 32 & 36 & 40 & 0 & 0 & 16 & 20 & 106 & 62 & 60 & 50 & -44 & -53 \\
\hline DEU & 78 & 20 & 53 & 55 & 0 & 34 & 27 & 77 & 62 & 77 & 38 & -49 & -67 \\
\hline HUN & 63 & 32 & 42 & 21 & 16 & 25 & 25 & 85 & 62 & 77 & 50 & -61 & -68 \\
\hline NLD & 52 & 54 & 44 & 60 & 1 & 35 & 17 & 39 & 46 & 80 & 63 & -46 & -62 \\
\hline NOR & 60 & 42 & 16 & 58 & 20 & 0 & 32 & 70 & 62 & 80 & 88 & -56 & -51 \\
\hline POL & 60 & 36 & 44 & 4 & 0 & 2 & 21 & 74 & 62 & 81 & 38 & -55 & -64 \\
\hline PRT & 62 & 53 & 26 & 52 & 13 & 26 & 13 & 66 & 62 & 82 & 75 & -58 & -59 \\
\hline ROU & 63 & 40 & 48 & 64 & 32 & 27 & 13 & 96 & 62 & 87 & 88 & -35 & -21 \\
\hline SVN & 48 & 36 & 26 & 76 & 32 & 18 & 4 & 66 & 56 & 90 & 75 & -65 & -73 \\
\hline SWE & 14 & 7 & 0 & 43 & 0 & 0 & 0 & 39 & 46 & 35 & 63 & -34 & -53 \\
\hline CHE & 57 & 45 & 62 & 76 & 0 & 15 & 15 & 57 & 60 & 73 & 63 & -56 & -68 \\
\hline Average & 52.9 & 39.7 & 36.7 & 51.5 & 10.3 & 21.4 & 20.8 & 74.3 & 59.3 & 76.1 & 67.0 & -50.7 & -59.0 \\
\hline
\end{tabular}

Source: Austrian National Tourist Office (2020); Hale et al. (2020); Statistics Finland (2020b); Romanian National Institute of Statistics (2020) 


\subsection{Methods}

Cluster analysis is an exploratory data technique consisting in identifying subsets in the data, such as the objects in a group are similar, while the objects in different clusters are different. One of the most used clustering algorithms is K-means, which is well-known for its simplicity.

K-means is an iterative algorithm that partitions a dataset into a predefined number of clusters denoted by K, such that one object belong to one cluster. The within cluster variation is minimized, such that the clusters are more homogeneous.

K-means algorithm has following steps:

1. The centroids are initialized randomly;

2. Each observation is assigned to the closest centroid;

3. The minimum (Euclidean) distance to the cluster centroid is computed for each observation. Centroids are recomputed as means of newly assigned observations.

We apply dynamically the K-means clustering algorithm over the period February-April 2020 to show the development from the beginning of policy responses in February to their full effect in April. The focus is on March, the month, when all countries under analysis had started their mitigation measures and when the largest variations of policy combinations took place.

The other applied method is principal component analysis (PCA), which is an unsupervised dimensionality reduction technique, based on an orthogonal transformation which transforms a set of usually correlated variables taking numerical values into a set of uncorrelated variables called principal components (PCs). The first PCs capture the most variance in the data. Each PC is orthogonal to the previous one and the first PC explains the most variance of the data. The PCA will use only the data from February to reveal which response components related to containment and closure policies are the most meaningful in explaining the variation in all data and which are linked to nights spent in the fifteen European countries under analysis. PCs are further used to build the Covid-Mitagation Index, which is used in country comparisons.

\section{ANALYSIS}

\subsection{K-means clustering}

We apply K-means algorithm for three months of data: February, March and April 2020. With the 15 countries and 3 months, this means $15 \times 3=45$ total cases.

The approach was chosen to study the dynamic development of the situation in the beginning of the Covid crisis. We chose to obtain 6 clusters, which lead to 2-3 clusters appering for each month as seen in Figure 1, which further show the distance of each country from the cluster center. Solid arrows in Figure 1 depict the countries showing up from the majority of countries, while dashed arrows depict that previously special countries align their policies with the majority of countries, i.e. they revert to the mean.

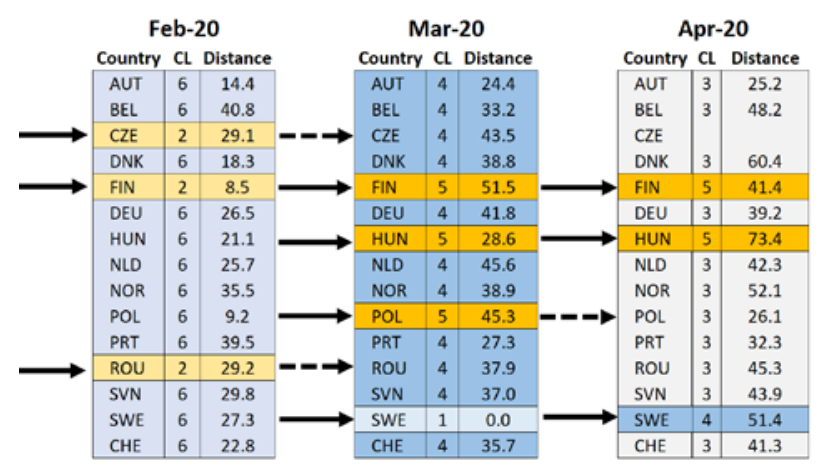

Figure 1. Dynamic K-means clustering and distances from cluster centers

Source: Own results (IBM SPSS Statistics 20) 
February 2020: Finland together with Czech Republic and Romania form a cluster in the beginning and the other 12 countries form another cluster. The tourism sector has not yet been hit by Covid-19 expect in Romania seen by a decline of $-6.8 \%$ in domestic (T1) and $-3.2 \%$ in foreign bednights (T2), in Slovenia $-9 \%$ in domestic bednights, and in Sweden $-3.1 \%$ in foreign bednights. On average of the 15 countries, the domestic bednights have still been growing by $7.4 \%$ and foreign bednights by $8.7 \%$ from the previous year. Only Germany had begun some School closings, Czech Republic cancelling some public events and Romania closing some public transports by the end of February. These policies had not yet affected tourism figures. Almost all countries had begun some Public information campaigns (H1); only Norway, Slovenia and Sweden had not responded at all and Finland, Czech Republic and Hungary only in the very end of the month. International travel controls (C8) had been set only in Czech Republic, Finland and Romania (and just in the end of the month in Germany). This is the major reason for the clustering results. Romania and Slovenia had been hit due to proximity of Italy, where the Covid-19 crisis had begun before the other European countries.

March 2020: Hungary and Poland join Finland to form a cluster in March, when Covid-19 hits tourism and all countries start almost all policy responses at some level. Domestic bednights (T1) have declined by $52.7 \%$ and foreign bednights (T2) by 63\% on average (Statistics Finland, 2020a, 2020b). Sweden and Denmark show the smallest decline of $-33.7 \%$ and $-34.2 \%$ in domestic bednights, respectively, and $-53.3 \%$ and $52.1 \%$ decline in domestic and foreign bednights, respectively. Romania and Czech Republic are now showing policy measures close to the majority of countries, which form the second cluster. Sweden is the most deviant country and it has not begun any policies related to cancelling public events (C3), closing public transport (C5), requirements of staying at home (C6), nor restrictions on internal movement (C7), and only very few workplace closings (C2), while Netherland set up the least restrictions on international traveling (C8) and given the least effort on public campaigns on the pandemic (H1). Finland, Hungary and Poland form a cluster as they show relatively low level, or zero level policies, specifically, with respect to C4-C7: Finland and Poland have not closed any public transport (C5) and Finland has not set up any restrictions on gatherings (C4) and Poland only in the very end of the month; Also Hungary show much under average restrictions on gatherings, but slightly above average, but not specifically high, in responses C5-C7. The decline in bednights is not far from total averages, very close to those in Hungary (-60.6\% and $-68.3 \%$, domestic foreign bednights, espectively) and Poland ( $-54.6 \%$ and $63.8 \%$, respectively), while Finland still shows under average declines by $-44 \%$ and $53.3 \%$ in domestic and foreign bednights, respectively.

April 2020: Tourism industry is hit hard in all countries: domestic bednights (T1) show $-87.0 \%$ and foreign bednights $-95.6 \%$ declines. Sweden with the least restrictions show the smallest declines (with Denmark by domestic bednights), i.e. $-64.8 \%$ and $-81.4 \%$ respectively (Denmark: $-45.2 \%$ and $-97.2 \%)$, and it still appears as its own cluster. Finland and Hungary appear still in their own cluster even their tourism figures are very close to the average in foreign bednights, while Hungary shows totally vanished domestic bednights, as well. The two countries differ from others specifically by not setting up either any restrictions on gatherings (Finland) or very little (Hungary).

\subsection{Principal component analysis}

Next, we apply PCA (Jolliffe, 2002) to reduce the number of variables by constructing new variables called principal components, as linear combinations of original variables. PCA helped identify the principal components related to tourisms activities affected by Covid. By IBM SPSS v20 four PCs were extracted from the correlation matrix according to the Kaiser criterion. The components with an eigenvalue greater than 1 are retained in table 3 . They explain together $\mathbf{7 6 . 1 5 2 \%}$ of the total variance. In table 3 we notice that the fourth PC is highly correlated with C4_Restrictions on gatherings and C5_Close public transport. Therefore, we will restrict our study to the first three PCs which account for $62.493 \%$ of the total variance. 
Table 3. Eigenvalues, variance percentage and cumulative variance percentage

\begin{tabular}{|l|l|l|l|}
\hline Component & Eigenvalue & Percentage of variance & Cumulative \% of variance \\
\hline PC1 & 3.837 & 22.197 & 22.197 \\
\hline PC2 & 1.853 & 20.449 & 42.646 \\
\hline PC3 & 1.446 & 19.847 & 62.493 \\
\hline PC4 & 1.240 & 13.659 & 76.152 \\
\hline
\end{tabular}

Source: Own results (IBM SPSS Statistics 20)

Table 4. Rotated component matrix

\begin{tabular}{|l|r|r|r|r|}
\cline { 2 - 5 } \multicolumn{1}{c|}{} & PC1 & PC2 & PC3 & PC4 \\
\hline H1_Public information campaigns & .913 & .238 & .073 & .047 \\
C8_International travel controls & .856 & -.009 & .027 & .092 \\
C7_Restrictions on internal movement & .609 & -.056 & .463 & -.322 \\
C1_School closing & .479 & .419 & .371 & .085 \\
\hline T2_Foreign_bednights & .051 & -.915 & -.175 & -.085 \\
T1_Domestic_bednights & -.153 & -.826 & -.053 & -.196 \\
C3_Cancel public events & .274 & .627 & .394 & -.477 \\
\hline C6_Stay at home requirements & .138 & .164 & .806 & -.047 \\
C2_Workplace closing & .203 & .174 & .711 & -.049 \\
C4_Restrictions on gatherings & -.285 & .053 & .694 & .515 \\
\hline C5_Close public transport & .180 & .207 & .010 & .915 \\
\hline
\end{tabular}

\section{Source: Own results (IBM SPSS Statistics 20)}

In table 4 we represented with bold fonts the factor loadings in absolute value greater than 0.5 (or around 0.5 ). According to PC1, public information campaigns (H1) are correlated with international travel controls (C8), restrictions on internal movement (C7) and school closing (C1). The positive part of PC2 is correlated with cancelling public events (C3), as opposed to foreign (T2) and domestic bednights (T1), which are correlated with the negative side. PC3 is positively correlated with stay at home requirements (C6), workplace closing (C2) and restrictions on gatherings (C4). PC4 is dominated by closure of public transport (C5).

A compound Covid-mitigation index (CMI) is built using the coefficients, or loadings, of the four PCs from Table 3 weigthed by the ratios of the proportion of the variance explained by each PC divided by the cumulated variance explained by the four PCs of Table 3.The CMI is formulated as:

$$
C M I=\text { Weight }_{1} \times P C 1+\text { Weight }_{2} \times P C 2+\text { Weight }_{3} \times P C 3+\text { Weight }_{4} \times P C 4,
$$

where the weights are computed as Weight $_{1}=22.197 / 76.152=29.148 \%$, Weight $_{2}=20.449 / 76.152=26.853 \%, \quad$ Weight $t_{3}=19.847 / 76.152=26.062 \%, \quad$ and Weight $_{4}=12.659 / 76.152=17.936 \%$ (cf. Table 3). And the elements of PCs are computed summimg up the weighted PC loadings for each variable (Table 4). For example, the coefficient for the most dominant variable $\mathrm{H} 1$, public information campaigns is $H 1$ coef ficient $=29.148 \% \times 0.913+26.853 \% \times 0.238+26.062 \% \times 0.73+17.936 \% \times$ 0.47 $=0.357$, and for the other 10 
coefficients accordingly. After ordering the components by their coefficients, we obtain the following composite index:

CMI $=0.364 \times C 1$ School closing
$+0.357 \times$ H1_Public information campaigns
$+0.286 \times$ C6_Stay_at_home_requirements
$+0.282 \times C 2$ Workplace_closing
$+0.275 \times C 5$ Close_public_transport
$+0.270 \times$ C8_International_travel_controls
$+0.265 \times C 3$ Cancel_public_events
$+0.225 \times C 7$ Restrictions_on_internal_movement
$+0.204 \times C 4$ Restrictions_on_gatherings
$-0.292 \times T 2$ Foreign_bednights
$-0.315 \times T 1$ _Domestic_bednights

Using the country-wise data and rescaling the CMI composite index by min-max normalization, we obtain Figure 2 showing that Romania (ROU) and Czech Republic (CZE) have the highest CMI values for March 2020 (100 and 96.5, respectively), while Sweden (SWE) on the bottom gets $\mathrm{CMI}=0$, and Finland (FIN) and Poland (POL) show the next lowest CMI values (51.6 and 57.5, respectively)

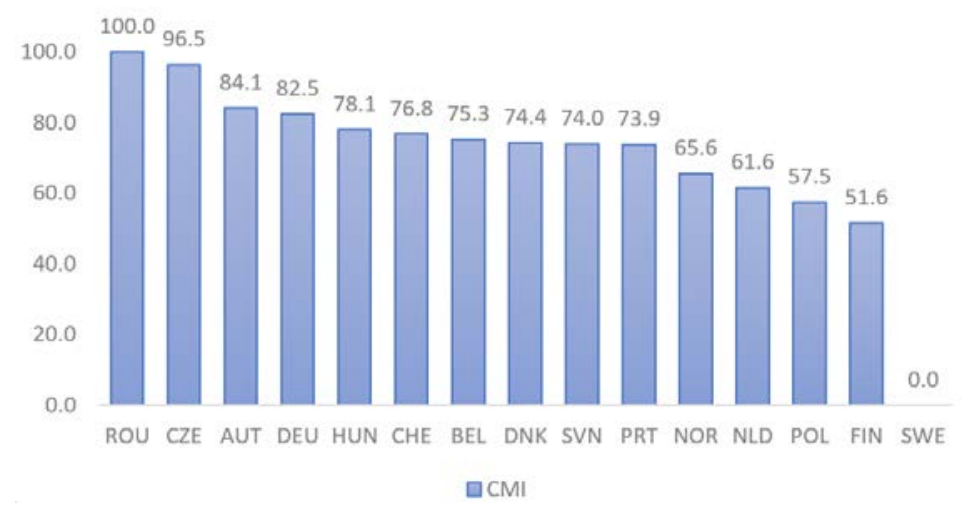

Figure 2. Composite Covid-Mitigation Index, CMI, for March 2020

Source: Own computations

\section{CONCLUSIONS}

We conducted, firstly, a clustering analysis over the three-months period from February to April 2020, when the European countries under analyses began their Covid-19 mitigation policies.

We found, in line with expectations, that Sweden is a special case. Sweden had set up the least restrictive policy measures, such are restrictions on gatherings and domestic and international travels. Special policy approach was seen taken also, for instance, by Romania, which was hit early due to effects from it neighboring Italy, from where the pandemic entered Europe, as well as, by Finland which showed similar policies with Romania still in February, but which after that continued with ones of the loosest policy combinations. Sweden and partly Denmark showed limited decline in (specifically, domestic) tourism, while the tourism industry, practically, in all other countries, were fully vanished.

The principal component analysis (PCA) showed that public information campaigns (H1) explained most of the total variance of all policy variables, together with international travel controls (C8), restrictions on internal travels (C7) and school closings (C1), which formed the first principal component, PC1. 
Next, the composite Covid-Mitigation Index, CMI, was constructed. The most important individual variables were also mainly from PC1, but also stay at home requirements (C6), workplace closings (C2) and closing public transport (C5) were the most important factors of CMI. Romania and Czech Republic showed the strongest policy approaches to obtain the highest values of CMI, while Sweden, Finland and Poland were represented by the smallest CMI values.

Some limitations of the study may be noted: the monthly tourism data from the tourism marketing information system, TourMIS, was limited and didn't allow including all European nor EU countries, which left out many interesting cases, such as Italy and Spain, for example. However, of the possible tourism variables, the used measure of bednights offered the best availability. With the fifteen countries under analysis, the generalizability to other than European countries may be problematic due to the complex nature of the phenomenon with numerous inter-connected factors, which are out of the scope of this study. For the future study, we would include all EU countries and also other European countries for reference as the European Union has led to some coordination of the mitigation policies of the member states. An interesting extension can be to study the impact of Covid-19 pandemic on the tourism supply chain performance (cf. Kot and Kozicka, 2018; Kot et al., 2018).

\section{ACKNOWLEDGEMENT}

The paper is part of Ane-Mari Androniceanu's doctoral research program at the Doctoral School of Management at Bucharest University of Economic Studies.

\section{REFERENCES}

Akeel, H. \& Khoj, H. (2020). Is education or Real GDP per capita helped countries staying at home during COVID-19 pandemic: cross-section evidence?. Entrepreneurship and sustainability Issues, 8(1), 841-852.

Androniceanu, A. (2020). Major structural changes in the EU policies due to the problems and risks caused by COVID-19. Administratiesi Management Public, 34, 137-149.

Angulo-Guerrero, M. J., Pérez-Moreno, S. \& Abad-Guerrero, I. M. (2017). How economic freedom affects opportunity and necessity entrepreneurship in the OECD countries. Journal of Business Research, 73, 30-37.

Austrian National Tourist Office (2020). Nights and arrivals in European countries: monthly data. Retrieved from https://www.tourmis.info/cgi-bin/tmintro.pl

Besenyő, J. \& Kármán, M. (2020). Effects of COVID-19 pandemy on African health, political and economic strategy. Insights into Regional Development, 2(3), 630-644.

Ciochina I., Iordache, C. M. \& Sîrbu, A. (2016). Entrepreneurship in the tourism and hospitality Industry. Management Strategies Journal, 31(1), 264-275.

Dvorský, J., Petráková, Z. \& Fialová, V. (2020). Perception of Business Risks by Entrepreneurs According to Experience with the Business Failure. International Journal of Entrepreneurial Knowledge, 8(1), 76-88.

Dung, H. C., Thanh, P. T. K., Oanh, D. V. \& Long, N. H. (2018). Local Government Involvement in Small Tourism Firms Investment: The Case of PhuTho Province, Vietnam. Economics and Sociology, 11(2), 97-111.

De Haan, J. \& Sturm, J.-E. (2000). On the relationship between economic freedom and economic growth. European Journal of Public Policy, 16(2), 215-241.

Georgescu, I., Androniceanu, A. \& Kinnunen, J. (2018). A Computational Analysis of Economic Freedom Indicators and GDP in EU States. Proceedings of the 17th International Conference on Informatics in Economy (IE 2018), Iasi, Romania, pp. 461-468. 
Georgescu, I. \& Kinnunen, J. (2019). Well-being and Economic Freedoms in OECD. Proceedings of the 12th LUMEN International Scientific Conference Rethinking Social Action (LUMEN RSACVP2019), Iasi, Romania, 107-125.

Hale, T., Webster, S., Petherick, A., Phillips, T. \& Kira, B. (2020). Stringency Index (OXBS). Oxford COVID-19 Government Response Tracker. Retrieved October 4, 2020,

from https://www.bsg.ox.ac.uk/research/research-projects/oxford-covid-19-governmentresponse-tracker.

Jolliffe, I. T. (2002). Principal Component Analysis. New York, NY: Springer-Verlag.

Kinnunen, J., Androniceanu, A. \& Georgescu, I. (2019). The Role of Economic and Political Features in Classification of Countries-in-Transition by Human Development Index. Informatică Economică, 23(4), 26-40.

Kinnunen, J. \& Georgescu, I. (2020a). Entrepreneurial activity - a matter of microeconomic conditions or macroeconomic freedoms?. Proceedings of the 5th Business and Entrepreneurial Economics Conference (BEE-2020), Rijeka, Croatia, 88-97.

Kinnunen, J., \& Georgescu, I. (2020b). Disruptive Pandemic as a Driver towards Digital Coaching in OECD Countries. Revista Romaneasca pentru Educatie Multidimensionala, 12(2Sup1), 5561.

Kostynets, I., Kostynets, V. \& Baranov, V. (2020). Pent-up demand effect at the tourist market. Economics and Sociology, 13(2), 279-288.

Kot, S. \& Kozicka, K. (2018). Supply chain management evidence from tourism industry in Greece. Journal of Environmental Management and Tourism, 9(4), 683-693.

Kot, S., Goldbach, I.R. \& Ślusarczyk, B. (2018). Supply chain management in SMES - Polish and Romanian approach. Economics and Sociology, 11(4), 142-156.

Lee-Ross, D. \& Lashley, C. (2009). Entrepreneurship and Small Business Management in the Hospitality Industry. Burlington, MA: Butterworth-Heinemann.

Mura, L. \& Kajzar, P. (2019). Small Businesses in Cultural Tourism in a Central European Country. Journal of Tourism and Services, 10(19), 40-54.

OECD (2020a). Tourism Policy Responses to the coronavirus (COVID-19), Retrieved from https://www.oecd.org/coronavirus/policy-responses/tourism-policy-responses-to-thecoronavirus-covid-19-6466aa20/

OECD (2020b). OECD Tourism Trends and Policies 2020. Paris, France: OECD Publishing.

Oxford COVID-19 Government Response Tracker (2020). Codebook for the Oxford Covid-19 Government Response Tracker: Codebook version 2.3. Retrieved July 05, 2020, from https://github.com/OxCGRT/covid-policy-tracker/blob/master/documentation/codebook.md

Pavlik, J. B. \& Geloso, V. (2020). Economic Freedom and the Economic Consequences of the 1918 Pandemic. Contemporary Economic Policy.

Poór, J., Engle, A.D., Ádám Kovács, Á., Albrychiewicz-Slocinska, A., Caha, Z., KumpikaiteValiuniene, V. et al. (2020). Initial findings for labour markets in the Czech Republic, Hungary, Poland and Slovakia. Central European Journal of Labour Law and Personnel Management, 3 (1), 46-59.

Razif, M., Miraja, B. A., Persada, S. F., Nadlifatin, R., Belgiawan, P.F., Redi, A. A. N. P. et al. (2020). Investigating the role of environmental concern and the unified theory of acceptance and use of technology on working from home technologies adoption during COVID-19. Entrepreneurship and Sustainability Issues, 8(1), 795-808.

Romanian National Institute of Statistics (2020). Turismul în luna martie 2020. Retrieved from https://insse.ro/cms/files/statistici/comunicate/turism/a20/turism03r20.xlsx

Štefko, R., Jenčová, S. \& Vašaničová, P. (2020). The Slovak Spa Industry and Spa Companies: Financial and Economic Situation. Journal of Tourism and Services, 20(11). 
Statistics Finland (2020a). Nights spent by foreign tourists in Finland decreased by 53 per cent in March 2020. Retrieved from http://www.stat.fi/til/matk/2020/03/matk_2020_03_2020-0429_tie_001_en.html

Statistics Finland (2020b). Accommodation statistics 2020. Retrieved from http://www.stat.fi/til /matk/2020/05/index_en.html

UN (2020). Covid-19 and Tourism: Assessing the Economic Consequences. Retrieved from https://unctad.org/en/PublicationsLibrary /ditcinf2020d3_en.pdf. 